\title{
DETERMINATION OF ADENOSINE TRIPHOSPHATE IN YEAST AND BLOOD
}

\author{
by \\ ELIZABETH P. STEYN PARVE \\ Laboratory for Physiological Chemistry, The University, Utrecht (Netherlands)
}

\section{INTRODUCTION}

Adenosine triphosphate (ATP) can be determined either by measuring the amount of labile phosphorus split off by Io minutes' hydrolysis in $\mathrm{N} \mathrm{HCl}$ at $\mathrm{I00}^{\circ 1}$, or by enzymic assay with myosin adenosinetriphosphatase, or myosin plus myokinase ${ }^{1,2}$. There is a general consensus of opinion that the first method only gives reliable results in the analysis of fresh, pure laboratory preparations of ATP. It follows that in all biological material ATP must be estimated by enzymic assay. A third possibility would lie in the employment of reactions in which ATP exerts a coenzyme function: c.q. hexokinase ${ }^{\mathbf{z}}$, thiaminokinase ${ }^{4}$. However, these reactions have the disadvantage of requiring relatively large amounts of ATP to produce measurable effects. Finally there are spectrophotometric methods ${ }^{5,6,7}$, but these are fairly complicated.

A major handicap in the application of myosin to the assay of ATP in biological material is that ATP must first be extracted from the tissues under examination, and that it has always been recommended to do this with trichloroacetic acid in the cold, as ATP would be easily injured by acid reaction. From such a trichloroacetic acid extract ATP must be isolated again before applying myosin, a cumbersome procedure, which, as we have seen and will be discussed below, incurs considerable losses from dilute solutions. Moreover, it is very difficult to extract ATP with cold trichloroacetic acid from fresh pressed yeast, which was our main objective in the determination of ATP.

We have therefore attempted - with favourable results - to extract ATP by one minute's boiling in dilute $\mathrm{HCl}$, in the same manner as is done for thiamine pyrophosphate $^{8}$. ATP is not damaged at all by this procedure, provided the $\mathrm{pH}$ does not drop below 2.5. The myosin test can be applied directly to the extracts thus obtained, after neutralizing and spinning down the debris. Yeast is extracted very easily in this manner.

In the following the elaboration of the procedure for the estimation of ATP in yeast is outlined, and its adaptation for the estimation in blood is described.

\section{EXPERIMENTAL}

\section{Materials and methods}

a. Myosin. Prepared from rat muscle as described by SteYn PARVE ANd GerRitsen ${ }^{8}$.

b. Adenosine triphosphate and adenosine diphosphate. ATP was prepared in the laboratory according to a slightly modified version ${ }^{10}$ of the prescription by Dounce et al.11. The monobarium References p. ז27. 
salt was converted into the potassium salt with $\mathrm{K}_{2} \mathrm{SO}_{4}$ before use. Adenosine diphosphate (ADP') was prepared from ATP by LoHMANN's method with Iobster muscle ${ }^{12,13}$

c. Yeast. Most work was done with fresh, pressed commercial bakers' yeast ("Koningsgist", Delft). Some tests were performed with fresh brewers' yeast from the "Amstel" brewery (Amsterdam).

d. Myosin test. Performed according to BaILEY's method ${ }^{1}$, slightly modified. Reaction mixtures always contained I $\mathrm{ml}$ substrate, I $\mathrm{ml} 0.5 M$ glycine buffer $\mathrm{pH} 8.5$, $0 . \mathrm{I} \mathrm{ml} \mathrm{CaCl}$ (o.I $M$ or $0.02 M$, see below) and $\mathrm{O} . \mathrm{t}$ to $0.2 \mathrm{ml}$ myosin solution (depending on its activity). Incubation took place at $27.5^{\circ} \mathrm{C}$ for 2 hours. After deproteinization with $0.5 \mathrm{ml}$ trichloroacetic acid $20 \%$ and standing in ice-cold water for 30 minutes the extracts were centrifuged and $2 \mathrm{ml}$ were used for the determination of inorganic phosphate. Blanks had the same composition as the test solutions, but here trichloroacetic acid was added immediately after adding myosin. The difference between test and blank gives the amount of $\mathbf{P}$ split off from ATP by myosin.

e. Determination of inorganic phosphate. Carried out according to SUMNER's method ${ }^{\mathbf{1 4}}$, with this modification that the total volume was 25 instead of $50 \mathrm{ml}$. A set of standard solutions containing $20,4^{\circ}, 60$ and $80 \gamma \mathrm{P}$ respectively was included in each series of determinations. Spectrophotometric measurement of light absorption was performed at $6800 \mathrm{~A}$ in the Beckman spectrophotometer, cell depth: io $\mathrm{mm}$.

\section{The resistance of $A T P$ against boiling in dilute acid}

From dilute solutions of ATP hardly any inorganic phosphate is liberated after boiling for one minute at $\mathrm{pH} 5,4$ or 3 : an o.Oor $M$ solution of ATP, containing 2 to $3 \gamma$ inorganic $\mathrm{P}$ per $\mathrm{ml}$, was found to contain 4 to $4.5 \gamma \mathrm{P}$ per $\mathrm{ml}$ after boiling at each of the afore-mentioned $\mathrm{pH}$ values. Only at $\mathrm{pH} 2$ there was a slight increase of inorganic $\mathrm{P}$, to $8.5 \gamma$ per $\mathrm{ml}$.

That ATP is indeed practically unimpaired by this treatment could be confirmed by applying the myosin test to samples of a solution of ATP before and after boiling for one minute at $\mathrm{pH}$ 2.5. Before boiling myosin liberated $49.5 \gamma \mathrm{P}$, as against $47 \gamma \mathrm{P}$ from the same amount of ATP after boiling.

So, contrary to the opinion generally held, it is possible to boil a solution of ATP for one minute at acid reaction, provided the $\mathrm{pH}$ is not below 2.5. It now appeared feasible to extract ATP from yeast by boiling for one minute at $\mathrm{pH} 2.5$ to 3 , as has been done for many years to prepare extracts containing thiamine pyrophosphate ${ }^{8}$.

\section{Experiments with yeast}

Extracts of bakers' yeast, one $\mathrm{ml}$ of which corresponded to 50 mg yeast, contained 45 to $50 \gamma$ inorganic $\mathrm{P}$ per $\mathrm{ml}$, and 30 to $80 \gamma$ labile $\mathrm{P}$, but were too dilute to provide clear-cut evidence of liberation of phosphate by myosin against this high background of inorganic $\mathrm{P}$.

We therefore attempted to concentrate ATP from a larger volume of extract and to get rid of the encumbering phosphate background by applying the purification procedure employed in the preparation of $\mathrm{ATP}^{1}$ : precipitation with $\mathrm{Ba}$ at $\mathrm{pH} 8.2$, followed by precipitation with $50 \%$ ethanol after dissolving the first precipitate in o.I $N \mathrm{HCl}$ and conversion of the barium salt into the potassium salt with $\mathrm{K}_{2} \mathrm{SO}_{4}$. This worked quite well with relatively concentrated solutions of pure ATP ( 4 to $8 \mu M / \mathrm{ml}$ ), of which at most 10\% was lost by the treatment. When $50 \mathrm{ml}$ of yeast extract (corresponding to $5 \mathrm{~g}$ yeast) were thus concentrated to $5 \mathrm{ml}$, measurable amounts of $\mathrm{P}$ were split off by myosin against a low background of inorganic $P$.

However, the amount of ATP calculated to be present in the yeast--less than I $\mu M / g$ fresh yeast - seemed to be low, and subsequent recovery experiments, in which known small amounts of ATP were added to the yeast extracts, showed that considerable losses of ATP occur (sometimes $60-70 \%$ in all), both in the first phase (precipitation 
with $\mathrm{Ba}$ ) and in the second phase (precipitation with ethanol) of the concentration procedure. It also appeared to be impossible to recover pure ATP from dilute solutions $(5 \mu M$ in $50 \mathrm{ml})$.

This procedure was abandoned and the myosin test was now applied at once to I $\mathrm{ml}$ of the most concentrated extracts which could be obtained directly from the yeast (40 $\mathrm{ml}$ extract from $5 \mathrm{~g}$ yeast). Notwithstanding the high background of inorganic $\mathrm{P}$, marked and reproducible differences were found in $\mathrm{P}$ content between test and blank experiments, when the light absorption was measured with a sensitive instrument (Beckman spectrophotometer). However, in recovery experiments the amount of inorganic P split off by myosin from ATP added to the yeast extract was now much too high.

This observation pointed to the presence of myokinase (adenylate kinase) in the yeast extract, which is known to be thermostable, at least that obtained from skeletal muscle. Indeed, more inorganic $\mathrm{P}$ was liberated from ADP in the presence of yeast extract than from ADP alone (Table I). The myokinase was destroyed by heating the extract for 4 minutes at $60^{\circ} \mathrm{C}$ with $0 . \mathrm{I} \% \mathrm{H}_{2} \mathrm{O}_{2}$, according to Colowick AND KaLCKAR's indications ${ }^{15}$. Excess $\mathrm{H}_{2} \mathrm{O}_{2}$ was thereupon removed by adding a drop of dilute laked blood (catalase). Now the amount of P liberated from ADP by myosin was the same, whether the yeast extract thus treated was present or not (Table I).

TABLE I

DECOMPOSITION OF ADP BY MYOSIN IN THE PRESENCE OF YEAST EXTRACT INFLUENCE OF TREATMENT OF EXTRACT TO REMOVE MYOKINASE

Preparation of extract: see text, p. 124. $0.8 \mathrm{ml}=$ 100 $\mathrm{mg}$ yeast. $\mathrm{A}=$ extract used as such. $\mathrm{B}=$ extract treated with $\mathrm{H}_{2} \mathrm{O}_{2}$ to remove myokinase (see text, $\mathrm{p}$. I23). Results expressed in $\gamma \mathrm{P}$ in total reaction mixture of myosin test.

\begin{tabular}{|c|c|c|c|c|c|}
\hline \multirow{2}{*}{ Exp. No. } & \multirow[b]{2}{*}{ Substrate } & \multicolumn{2}{|c|}{ A. Untreated } & \multicolumn{2}{|c|}{ B. Treated } \\
\hline & & $\gamma_{\text {by myosin }}^{P \text { liberated }}$ & $\begin{array}{c}\text { Difference } \\
2-I\end{array}$ & $\gamma \underset{\text { by myosin }}{P \text { liberated }}$ & $\begin{array}{c}\text { Difference } \\
2-I\end{array}$ \\
\hline $\mathbf{I}$ & $0.8 \mathrm{ml}$ extract $+0.2 \mathrm{ml} \mathrm{H}_{2} \mathrm{O}$ & 5.5 & & 5.5 & \\
\hline 2 & $0.8 \mathrm{ml}$ extract $+0.2 \mathrm{ml} \mathrm{ADP}^{\star}$ o.o $M$ & 21.5 & I6.0 & $15 \cdot 5$ & 10.0 \\
\hline 3 & $0.8 \mathrm{ml} \mathrm{H}_{2} \mathrm{O}+0.2 \mathrm{ml} \mathrm{ADP}^{\star}$ o.0I $M$ & 9.0 & & 8.5 & \\
\hline
\end{tabular}

* The ADP still contained a little ATP

The amount of $\mathrm{P}$ split off by myosin from ATP added to the treated yeast extract was now Io to $20 \%$ too low. It was considered likely that this loss would be due to the inhibition of ATP-ase by the large amounts of inorganic phosphate present in the yeast extract. This has already been observed by BAILEY ${ }^{1}$ and could be confirmed in tests in which o to $200 \gamma$ inorganic $\mathrm{P}$ (as $\mathrm{Na}_{2} \mathrm{HPO}_{4}$ ) were added to I $\mu M$ ATP: from 50 to $200 \gamma \mathrm{P}$ an increasing inhibition of 4.5 to $15 \%$ was observed.

This inhibition of ATP-ase by phosphate may be either competitive or it may be that ATP is adsorbed to the precipitate which is formed when calcium ions, required as activator, are added to the test solution, and that this adsorbed ATP cannot be decomposed by the enzyme. When the calcium phosphate precipitate was removed by centrifuging before adding myosin, the amount of $\mathbf{P}$ split off was still less than in the presence of the precipitate, so ATP is indeed adsorbed to some extent, but this adsorbed ATP is still partly decomposed by myosin (Table II). 
TABLE II

INFLUENCE OF REMOVAL OF CALCIUM PHOSPHATE PRECIPITATE UPON THE DECOMPOSITION OF ATP BY MYOSIN

Experiments in duplicate. Inorganic $\mathrm{P}$ added as $\mathrm{Na}_{2} \mathrm{HPO}_{4} .5$ and 6 : same composition as 3 and 4 , but double volume. All tubes in ice-water for 30 minutes before adding myosin. Tubes 5 and 6 centrifuged and half volume transferred to new tubes. Myosin now added to all tubes. Results expressed in $\gamma \mathrm{P}$ in total reaction mixture of myosin test.

\begin{tabular}{|c|c|c|c|c|}
\hline Exp. No. & Substrate & Tesi & Blank & $\gamma_{b y \text { myosin }}^{P \text { liberated }}$ \\
\hline $\left.\begin{array}{l}I \\
2\end{array}\right\}$ & $\mathrm{I} .2 \mu M \mathrm{ATP}$ & $\begin{array}{l}44 \\
45\end{array}$ & $\begin{array}{l}7 \\
7\end{array}$ & $\begin{array}{l}37 \\
38\end{array}$ \\
\hline $\left.\begin{array}{l}3 \\
4\end{array}\right\}$ & I. $2 \mu M$ ATP + Ioo $\gamma \mathrm{P} ;$ precipitate present & $\begin{array}{l}\text { I } 34 \\
\text { I } 35.5\end{array}$ & $\begin{array}{l}104 \\
105.5\end{array}$ & $\begin{array}{l}30 \\
30\end{array}$ \\
\hline $\left.\begin{array}{l}5 \\
6\end{array}\right\}$ & I.2 $\mu M$ ATP + roo $\gamma \mathrm{P}$; precipitate removed & $\begin{array}{l}66 \\
66.5\end{array}$ & $\begin{array}{l}46 \\
47\end{array}$ & $\begin{array}{l}20 \\
19.5\end{array}$ \\
\hline
\end{tabular}

By adding less calcium the formation of a precipitate can be avoided. For yeast extract this was the case when $0.1 \mathrm{ml}$ o.I $M \mathrm{CaCl}_{2}$ was replaced by $0.1 \mathrm{ml} 0.02 M \mathrm{CaCl}_{2}$. This amount of calcium is still sufficient for maximal activation of ATP-ase. The recovery of added ATP is then still slightly too low (about ro \%), so there must also be some other kind of inhibition of ATP-ase by inorganic phosphate in solution (Table III). However, we feel this may be neglected, as it is usually sufficient to know the content of ATP with 10\% error.

\section{TABLE III}

INHIBITION OF ADENOSINETRIPHOSPHATASE (MYOSIN) BY INORGANIC PHOSPHATE IN THE PRESENCE OF LITTLE CALCIUM

Experiments in duplicate. Inorganic $\mathrm{P}$ added as $\mathrm{Na}_{2} \mathrm{HPO}_{4}$. $0.1 \mathrm{ml} 0.02 \mathrm{M} \mathrm{CaCl}$ added in all cases. No calcium phosphate precipitate. Results expressed in $\gamma \mathrm{P}$ in total reaction mixture of myosin test.

\begin{tabular}{|c|c|c|c|c|c|}
\hline \multirow{2}{*}{ Exp. No. } & \multirow{2}{*}{ Substrate } & \multirow{2}{*}{ Test } & \multirow{2}{*}{ Blank } & \multicolumn{2}{|c|}{$\gamma P$ liberated by myosin } \\
\hline & & & & Found & Theoretical \\
\hline $\left.\begin{array}{l}1 \\
2\end{array}\right\}$ & $1.2 \mu M$ ATP & $\begin{array}{l}43 \\
43\end{array}$ & $\begin{array}{l}6.5 \\
6.5\end{array}$ & $\begin{array}{l}36.5 \\
36.5\end{array}$ & 37 \\
\hline $\left.\begin{array}{l}3 \\
4\end{array}\right\}$ & $\mathrm{I} .2 \mu M$ ATP $+\operatorname{Ioo} \gamma \mathrm{P}$ & $\begin{array}{l}\text { I } 38.5 \\
\text { I } 39.5\end{array}$ & $\begin{array}{l}105 \cdot 5 \\
107\end{array}$ & $\begin{array}{l}33 \\
32.5\end{array}$ & 37 \\
\hline
\end{tabular}

The final procedure adopted for the determination of ATP in yeast is as follows: Io $\mathrm{g}$ of fresh, pressed yeast are washed three times on the centrifuge with roo $\mathrm{ml}$ distilled water and suspended to a volume of $20 \mathrm{ml}$. ro $\mathrm{ml}$ of the suspension are pipetted into $25 \mathrm{ml}$ boiling $0.08 \mathrm{~N} \mathrm{HCl}$. The mixture is boiled for one minute, cooled in running tap water for one minute, and neutralized by adding approximately $3.4 \mathrm{ml} \mathrm{10} \% \mathrm{KOH}$. The volume is made up to $40 \mathrm{ml}$ with water and the yeast residue is centrifuged down. 
Io $\mathrm{ml}$ of the clear yellow extract, of $\mathrm{pH}$ about 7 , are heated for 4 minutes in a water bath of $60^{\circ}$ after adding o.I ml 10\% $\mathrm{H}_{2} \mathrm{O}_{2}$. After cooling the excess $\mathrm{H}_{2} \mathrm{O}_{2}$ is removed by adding $0.05 \mathrm{ml}$ of a twenty-fold dilution of fresh blood. The extract is brought to $\mathrm{pH} 8.5$ by adding a drop of $10 \% \mathrm{KOH}$ and I $\mathrm{ml}$ is used in the myosin test, carried out as described on p. I22 with o.I ml $0.02 \mathrm{M} \mathrm{CaCl}_{2}$. To test the ATP-ase activity of the myosin a known amount of pure ATP is always assayed simultaneously with the yeast extract.

In this manner ATP has been determined in several batches of fresh bakers' yeast and also in fresh brewers' yeast (Table IV). We find that the content is usually about $2 \mu M$ ATP per $g$ fresh yeast. With brewers' yeast, which contained slightly less inorganic phosphate, the recovery of added ATP was better than in the case of bakers' yeast.

\section{TABLE IV}

DETERMINATION OF ATP IN YEASTS WITH MYOSIN ADENOSINETRIPHOSPHATASE

For preparation and treatment of extracts see text, p. 124. Results expressed in $\gamma \mathbf{P}$ in total reaction mixture of myosin test; ATP in $\mu M$ per $\mathrm{g}$ fresh yeast. Lib. $=\gamma \mathrm{P}$ liberated by myosin.

\begin{tabular}{|c|c|c|c|c|c|c|c|c|c|c|}
\hline \multirow{3}{*}{ Yeast } & \multicolumn{9}{|c|}{ Substrate } & \multirow{3}{*}{$\underset{\mu M}{A T P}$} \\
\hline & \multicolumn{3}{|c|}{$\begin{array}{l}0.8 \mathrm{ml} \text { extract } \\
0.2 \mathrm{ml} \mathrm{H}_{2} \mathrm{O}\end{array}$} & \multicolumn{3}{|c|}{$\begin{array}{l}0.8 \text { ml extract } \\
0.2 \mathrm{ml} \mathrm{ATP} 0.006 \mathrm{M}\end{array}$} & \multicolumn{3}{|c|}{$\begin{array}{c}0.8 \mathrm{ml} \mathrm{H}_{\mathrm{g}} \mathrm{O} \\
0.2 \mathrm{ml} \mathrm{ATP} 0.006 \mathrm{M}\end{array}$} & \\
\hline & Test & Blank & $L i b$. & Test & Blank & Lib. & Test & Blank & $L i b$. & \\
\hline Bakers' I & 118.0 & II3.0 & 5.0 & I 56.0 & I I 4.5 & $4 \mathrm{I} \cdot 5$ & 45.0 & $7 \cdot 5$ & $37 \cdot 5$ & I.6 \\
\hline Bakers' II & 90.5 & 84.0 & 6.5 & 126.5 & 86.0 & 40.5 & $44 \cdot 5$ & $7 \cdot 5$ & 37.0 & 2.1 \\
\hline $\begin{array}{l}\text { Bakers' III * } \\
\text { (same batch as II) }\end{array}$ & 90.0 & $84 \cdot 5$ & $5 \cdot 5$ & I26.0 & 86.5 & $39 \cdot 5$ & $45 \cdot 5$ & 8.0 & $37 \cdot 5$ & $\mathrm{I} .8$ \\
\hline Brewers' $I^{\star \star}$ & 78.5 & $7 \mathrm{r} \cdot 5$ & 7.0 & I $17 \cdot 5$ & 72.5 & $44 \cdot 0$ & $45 \cdot 0$ & 8.0 & 37.0 & 2.3 \\
\hline Brewers' II * * & 87.0 & 79.0 & 8.0 & 125.5 & 83.0 & 42.5 & $44 \cdot 5$ & 9.0 & $35 \cdot 5$ & 2.6 \\
\hline
\end{tabular}

dry matter: $\mathbf{2 7 . 2} \%$

* dry matter: $21.6 \%$

\section{Determination of ATP in blood}

Challenged by a paper by WOLFF AND PAYSANT ${ }^{16}$, who determine ATP in blood by measuring acid-labile $\mathbf{P}$ and applying an empirical correction factor to discount hydrolysis of other phosphate esters, we have applied our method to blood.

Extracts were made of $2 \mathrm{ml}$ fresh blood in the manner described for the determi. nation of thiamine pyrophosphate ${ }^{8}$. Myokinase appeared to be absent, for the same amount of phosphate was split off from added ATP by myosin, whether the extract was treated to remove myokinase or not. So this treatment could be omitted and the myosin test was directly applied to $\mathrm{x} \mathrm{ml}$ extract as described above. Recovery of added ATP was 93-98\%. The blood extracts contain much less inorganic phosphate than the yeast extracts. A slight turbidity appears during the phosphate determination, but this is not disturbing, as test and blank samples display the same turbidity.

Determinations in blood of a number of human subjects, both male and female, indicate that there is remarkably little variation in their ATP content, which lies between I.o and I.5 $\mu M$ ATP per ml blood (Table V). 
TABLE V

DETERMINATION OF ATP IN BLOOD WITH MYOSIN ADENOSINETRIPHOSPHATASE

For preparation of extracts and other particulars, see text, p, $125.1 \mathrm{ml}$ extract corresumel: to $4 / 9 \mathrm{ml}$ blood. Determinations in duplicate, including preparation of extracts.

\begin{tabular}{|c|c|c|c|c|c|}
\hline $\begin{array}{l}\text { Subject } \\
\text { No. }\end{array}$ & Sex & $\begin{array}{l}\text { Test } \\
\gamma P\end{array}$ & $\begin{array}{l}\text { Blank } \\
\because P\end{array}$ & $\begin{array}{c}\gamma_{\text {by liberated }} \\
\text { by mosin }\end{array}$ & $\underset{\text { blood }}{A T P}, \mathrm{ml}$ \\
\hline I & $\mathrm{m}$ & $\begin{array}{l}42.0 \\
40.0\end{array}$ & $\begin{array}{l}21.0 \\
19.5\end{array}$ & $\begin{array}{l}2 \mathbf{I} .0 \\
20.5\end{array}$ & I .5 \\
\hline $2^{\star}$ & $\mathrm{m}$ & $\begin{array}{l}4^{6.0} \\
4^{8.5}\end{array}$ & $\begin{array}{l}27.0 \\
27.0\end{array}$ & $\begin{array}{l}19.0 \\
21.5\end{array}$ & I.2 \\
\hline 3 & $\mathrm{~m}$ & $\begin{array}{l}4^{6.5} \\
4^{8.0}\end{array}$ & $\begin{array}{l}28.0 \\
30.0\end{array}$ & $\begin{array}{l}18.5 \\
18.0\end{array}$ & 1.1 \\
\hline 4 & $\mathrm{~m}$ & $\begin{array}{l}47.0 \\
49.0\end{array}$ & $\begin{array}{l}27.5 \\
29.0\end{array}$ & $\begin{array}{l}19.5 \\
20.0\end{array}$ & 1,2 \\
\hline 5 & $\mathfrak{f}$ & $\begin{array}{l}51.0 \\
51.0\end{array}$ & $\begin{array}{l}32.5 \\
32.0\end{array}$ & $\begin{array}{l}18.5 \\
19.0\end{array}$ & I. 1 \\
\hline 6 & $f$ & $\begin{array}{l}5 \mathrm{O} .5 \\
5^{\mathrm{I}} .5\end{array}$ & $\begin{array}{l}32.0 \\
33.5\end{array}$ & $\begin{array}{l}18.5 \\
18.0\end{array}$ & 1.1 \\
\hline 7 & $\mathfrak{f}$ & $\begin{array}{l}5 \mathrm{I} .0 \\
48.5\end{array}$ & $\begin{array}{l}30.5 \\
29.0\end{array}$ & $\begin{array}{l}20.5 \\
19.5\end{array}$ & 1.2 \\
\hline
\end{tabular}

* In exp. 2-7 the myosin used split off slightly more than I P per ATP; it has often been observed that when preparations age, they first split off less $P$, and later more $P$ than the theoretical value. Appropriate correction has been applied to calculate ATP from P liberated.

\section{DISCUSSION}

The method described here for the determination of ATP in yeast and blood, although far from being ideal, is specific and reasonably accurate. Tentative experiments have shown that it can also be applied to animal tissues. To avoid losses of ATP from these tissues by the action of ATP-ase, the animal must be killed by severing the carotid artery under complete anaesthesia, and the tissues must be frozen in liquid air, pulverized and thrown into boiling dilute $\mathrm{HCl}$ in frozen state ${ }^{17}$. The exact strength of the acid required to obtain a $\mathrm{pH}$ of 2.5 to 3 ( $\mathrm{ro} \mathrm{ml}$ for each $\mathrm{g}$ of tissue), must he determined by preliminary experiment.

The high background of inorganic phosphate in some materials, as in yeast, is a disadvantage for accurate measurement. From numerous experiments, however, we have seen that with careful operation and measurement with a sensitive instrument deviations of duplicates are not more than I $\gamma \mathrm{P}$, which would seem to be sufficiently accurate. The method of extracting with boiling dilute $\mathrm{HCl}$ has the advantage of permitting direct enzymic assay with myosin in the extract thus obtained.

Other methods of enzymic assay have also been tried out. Potato apyrase, whether prepared according to KWAN HUA LEE AND EILER ${ }^{18}$ or KRISHNAN ${ }^{19}$, was not sufficiently specific. Purified preparations still decomposed a little inorganic pyrophosphate, and were, moreover, less active than myosin in completely decomposing ATP. Thiaminokinase, the enzyme that forms thiaminepyrophosphate (TPP) from thiamine and ATP, was not satisfactory either. Manometric measurement of TPP formed from small amounts of ATP gave inconsistent results, and with amounts of ATP below $0.4 \mu M / 0.8 \mathrm{ml}$ there was no clear-cut effect. 
The author is very much indebted to Prof. H. G. K. Westenerink for his continued interest and stimulating criticism, and to Miss A. G. ZW.ART for her able assistance with the experimental work.

\section{SUMMARI}

A method is described for the determination of ATP in yeast and blood, in which use is made of the decomposition of ATP by myosin adenosinetriphosphatase.

ATP is extracted without injury by one minute's boiling at $\mathrm{pH} 2.5$ to 3 .

Yeast extracts contain myokinase. To destroy this enzyme they are treated with o.I $\% \mathrm{H}_{2} \mathrm{O}_{2}$ at $60^{\circ} \mathrm{C}$ for 4 minutes and excess $\mathrm{H}_{2} \mathrm{O}_{2}$ is removed by a drop of dilute laked blood. The myosin test is then applied to the treated extract. Blood extracts do not contain myokinase.

Fresh pressed yeast contains about $2 \mu M$ ATP per g, human blood contains I-I.5 $\mu M$ ATP/ml.

\section{RÉSUMÉ}

L'auteur décrit une méthode de détermination d'ATP dans la levure et le sang; cette méthode est basée sur la décomposition de l'ATP par l'adénosinetriphosphatase de la myosine.

L'ATP est extrait à l'état intact par ébullition d'une minute à un $\mathrm{pH}$ de 2.5 à 3 .

Les extraits de levure contiennent de la myokinase. Pour détruire cet enzyme on traite pendant 4 minutes par o. $\%$ d' $\mathrm{H}_{2} \mathrm{O}_{2}$ à $60^{\circ}$, puis on détruit l'excès d' $\mathrm{H}_{2} \mathrm{O}_{2}$ par une goutte de sang haemolysé dilué. Le test de myosine est ensuite appliqué à l'extrait ainsi traité. Les extraits de sang ne contiennent pas de la myokinase.

La levure pressée fraîche contient environ $2 \mu M$ d'ATP par g, le sang humain en contient $\mathrm{I}-\mathrm{r} .5 \mu M$ par ml.

\section{ZUSAMMENFASSUNG}

Eine Methode zur Bestimmung von ATP in Hefe und Blut wird beschrieben. Sie gründet sich auf die Zersetzung von ATP durch Myosin-Adenosintriphosphatase.

ATP wird unversehrt durch Kochen während einer Minute bei pH 2.5-3 extrahiert.

Hefeextrakte enthalten Myokinase. Zur Zerstörung dieses Enzyms werden sie 4 Minuten bei $60^{\circ}$ mit $0.1 \% \mathrm{H}_{2} \mathrm{O}_{2}$ behandelt und der Überschuss an $\mathrm{H}_{2} \mathrm{O}_{2}$ mit einem Tropfen verdünnten hämolysierten Blutes entfernt. Mit dem behandelten Extrakt wird dann der Myosintest ausgeführt. Blutextrakte enthalten keine Myokinase.

Frische Presshefe enthält ungefähr $\_\mu M$ ATP pro g, menschliches Blut I-I.5 $\mu M$ ATP pro ml.

\section{REFERENCES}

1 K. BAlleY, Biochem. J., 45 (1949) 479.

2 S. L. Rowles and I.. A. Stocken, Biochem. J., 47 (I950) 489.

${ }^{3}$ H. M. Kalckar, $J$. Biol. Chem., I 48 (I943) I27.

4 E. P. Steyn Parve, Biochim. Biophys. Acta, 8 (1952) 310.

${ }^{5}$ H. M. KalckaR, J. Biol. Chem., I67 (1947) 445 .

6 A. Kornberg, J. Biol. Chem., I82 (I950) 779.

7 E. C. Slater, Biochem. J., 5o (I95I) vii.

8 H. G. K. Westenbrink and E. P. Steyn Parvé, Int. Rev. Vitamin Res., 2 I (1950) $46 \mathrm{I}$.

- E. P. Steyn Parvé and T. Gerritsen, Biochim. Biophys. Acta, 8 (1952) ro4.

10 T. GERRITSEN, Thesis, Utrecht x95I.

11 A. L. Dounce, A. Rothstein, G. T. Beyer, R. Meier and R. M. Freer, J. Biol. Chem., I74 (I948) 36I.

12 K. LohmanN, Biochem. $Z$., 282 (I935) Io9.

13 H. E. Carter, Biochemical Preparations I, p. I. New York, I949.

14 J. B. Summer, Science, IOO (I944) 4 I3.

$15 \mathrm{~S}$. P. Colowick and H. M. KalCKar, J. Biol. Chem., I 48 (I943) I I 7 .

16 R. Wolff and P. Paysant, Bull. soc. chim. biol., 33 (1951) 1877.

17 G. A. LePage, in Umbreit, BuRris and StAUfFer: Manometric Techniques and Tissue Metabolism, and edition, p. I85. Minneapolis I95I.

18 Kwan Hua Lee and J. J. Eiler, Science, ir 4 (195I) 393

19 P. S. Krishnan, Arch. Biochem., 20 (1949) $261,272$. 